\title{
Resilience of Oregon white oak to reintroduction of fire
}

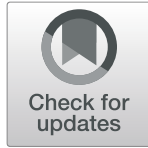

\author{
Deborah G. Nemens ${ }^{1,2^{*}}$ D, J. Morgan Varner ${ }^{2}$ and Peter W. Dunwiddie ${ }^{1}$
}

\begin{abstract}
Background: Pacific Northwest USA oak woodlands and savannas are fire-resilient communities dependent on frequent, low-severity fire to maintain their structure and understory species diversity, and to prevent encroachment by fire-sensitive competitors. The re-introduction of fire into degraded ecosystems is viewed as essential to their restoration, yet can be fraught with unintended negative consequences. We examined the response of mature Oregon white oak (Quercus garryana Douglas ex Hook:; Garry oak) to "first entry" woodland restoration burns following long fire-free periods.

Results: Thirteen to twenty-five months post burn, topkill of oaks was minimal (3\%) and mortality was rare in three prescribed burns, despite high levels (mean $=92 \%$ ) of crown scorching, and irrespective of proportional duff consumption around oak bases (mean $=21 \%$ ). Percentage of crown scorch volume was the strongest predictor of oak crown dieback, but response was highly variable, especially when canopy scorch was $\geq 80 \%$. Comparison of our results with FOFEM (First Order Fire Effects Model), a common fire effects model, revealed high model inaccuracy, likely due to lack of a species-specific equation for prediction of Oregon white oak mortality.

Conclusions: The results of this study indicate that Oregon white oak is highly resistant to mortality in restoration burns, even following long fire-free intervals. Prescribed fire is not contraindicated in areas with extant mature oaks, and may promote oak regeneration via basal sprouting.
\end{abstract}

Keywords: fire effects, FOFEM, oak woodland restoration, post-fire mortality, prescribed fire, Quercus garryana, resprouting, topkill

\section{Resumen}

Antecedentes: Los bosques de roble y sabanas del Pacífico noroeste de los EEUU, son comunidades resilientes al fuego, dependiendo de fuegos frecuentes de baja severidad que permiten mantener la estructura y diversidad de especies en el sotobosque, y previenen la invasión de especies sensibles al fuego. La re-introducción del fuego en ecosistemas degradados es vista como esencial para su restauración, aunque puede estar plagada de consecuencias negativas no previstas. Examinamos la respuesta de rodales maduros de roble blanco de Oregón (Quercus garryana Douglas ex Hook.; Garry oak) como primer registro de quemas prescriptas de restauración posteriores a un largo período sin fuegos.

(Continued on next page)

\footnotetext{
* Correspondence: dnemens@uw.edu

${ }^{1}$ School of Environmental and Forest Sciences, University of Washington, Box

352100, Seattle, Washington 98195, USA

${ }^{2}$ Pacific Wildland Fire Sciences Laboratory, USDA Forest Service Pacific

Northwest Research Station, 400 N 34th Street, Suite 201, Seattle,

Washington 98103, USA
} 
(Continued from previous page)

Resultados: De trece a veinticinco meses después de la quema, la muerte apical de los robles fue mínima (3\%) y la mortalidad fue rara en tres quemas prescriptas, a pesar de los altos niveles (media =92\%) del chamuscado de la corona, e independientemente de la proporción del consumo de mantillo alrededor de la base de los troncos de roble (media $=21 \%$ ). El porcentaje de chamuscado de la corona fue el predictor más fuerte de la mortalidad del roble, aunque la respuesta fue altamente variable, especialmente cuando el chamuscado de la corona fue $\geq 80 \%$. La comparación de nuestros resultados con el FOFEM (Modelo de Efectos del Fuego de Primer Orden), un modelo común de efectos del fuego, reveló un alto error del modelo, debido probablemente a la falta de ecuaciones especie-específicas para la predicción de mortalidad del roble blanco de Oregón.

Conclusiones: Los resultados de este estudio indican que el roble blanco de Oregón es altamente resistente a la mortalidad en quemas prescriptas, aun luego de grandes intervalos de tiempo libres de fuegos. Las quemas prescriptas no son contraindicadas en áreas con existencias de robles maduros, y pueden promover la regeneración de los robles vía rebrote basal.

\section{Abbreviations}

BCC: circumference charred at base $\mathrm{DBH}$ : diameter at breast height

DBHCC: circumference charred at breast height,

FOFEM: First Order Fire Effects Model HLD01 and HLD02: Holden Woods units

JBLM: Joint Base Lewis-McChord

PCVC: percent of crown volume consumed

PCVF: percent crown volume flushing

PCVS: percent crown volume scorched

UWTB and UWTT: Upper Weir units

\section{Background}

Frequent fire is a key mechanism for the maintenance of woodlands and savannas, providing regular disturbance that protects these unique ecosystems from transition into forests or shrublands (Bond and van Wilgen 1996; Bond and Keeley 2005). Due to this characteristic high fire frequency, fires in these ecosystems are typically of low severity, preventing encroachment by fire-intolerant plants while allowing a suite of fire-adapted species to maintain dominance (Staver et al. 2011a, b). The exclusion of fire from these systems can have varied unintended consequences, including the invasion of non-native plants and other species that can transform ecosystems, reduce species richness, and degrade habitat for dependent wildlife (Agee 1993; Varner et al. 2005; Nowacki and Abrams 2008). As a result, woodlands and savannas are the focus of restoration efforts around the world (Hanberry et al. 2017).

An archetypal fire-dependent ecosystem, Oregon white oak (Quercus garryana Douglas ex Hook.; Garry oak) woodlands and savannas were sustained for millennia by indigenous burning and lightning-ignited fires that favored fire-tolerant oaks and prevented the encroachment of the rapidly growing native competitor, Douglas-fir (Pseudotsuga menziesii var. menziesii [Mirb.] Franco) and other woody species (Agee 1993, 1996; Sprenger and Dunwiddie 2011). Once common across the lowlands of the Pacific Northwestern United States, oak woodlands, savannas, and associated prairies have been substantially reduced in both quality and extent in the years since Euro-American settlement (Chappell and Crawford 1997; Crawford and Hall 1997). These critically important plant communities support an array of rare plants, invertebrates, birds, and mammals that are absent in adjacent conifer-dominated forests (Larsen and Morgan 1998; Altman 2011). Further encroachment by Douglas-fir and other native and nonnative plants now threatens the remaining fragments of oak woodland and savanna in the region (Schriver et al. 2018).

To help restore Oregon white oak ecosystems, managers have increased their use of prescribed fire to control woody species, increased bare ground for native herbaceous plant establishment, and prepared sites for herbicide application to control non-native forbs and grasses (Sugihara and Reed 1987; Agee 1996; Tveten and Fonda 1999; Dennehy et al. 2011; Dunwiddie and Bakker 2011; Engber and Varner 2012; Livingston et al. 2016). Common practice aims for a fire return interval of 3 to 5 years, approaching historical fire regimes (Hamman et al. 2011; Sprenger and Dunwiddie 2011). Oregon white oak is considered a fire-resistant species, employing survival strategies such as protective bark and adventitious buds that can quickly resprout following damage in fire (Agee 1993; Gucker 2007). Despite this, long periods of fire exclusion increase the risk of unintended consequences in oak woodland restoration burns (Cole 1977; Taylor and Skinner 2003; Sugihara et al. 2006; Sprenger and Dunwiddie 2011). Of particular concern are greater fuel loadings and smaller fuel strata gaps due to woody plant encroachment, as well as accumulated forest floor duff (Oe and Oa organic soil horizons) around the bases of mature oaks. These characteristics of longunburned woodlands can increase fire severity in an ecosystem that is adapted to the low-intensity fire propagated in light, herbaceous fuels and a shorter, sparser 
shrub stratum (Agee 1993, 1996). Managers concerned about injury to oaks during prescribed fires often attempt to limit fire intensity around mature trees during burns by reducing surrounding fuels during burn unit preparation, managing firing techniques, and conducting burns under moderate weather conditions in order to maintain short flame lengths (J. Richardson, Fish and Wildlife Program, Joint Base Lewis-McChord, Washington, USA, personal communication). These actions are taken under the presumption that scorching in the crown will injure or even kill overstory oaks. These preparations and precautions can present operational difficulties due to the additional labor required and a shortened burning season, and often precludes the treatment of large areas with restoration burns.

Previous studies have found that extensive crown scorch can cause mortality in a variety of conifer species (Hood et al. 2018), as well as result in topkill among some oak species (Babb 1992), but this relationship has not been well examined for Oregon white oak. Longduration smoldering of accumulated basal duff can also injure or kill trees via cambial injury or harm to fine roots in long-unburned sites (Swezy and Agee 1991; Miyanishi and Johnson 2002; Stephens and Finney 2002; Varner et al. 2005; Varner et al. 2009). These studies, however, examined below-ground fire effects on conifers and, to our knowledge, no studies of duff consumption and its potential causal relationship to tree injury have been conducted in oak-dominated systems.

To better understand the mechanisms of fire-induced oak injury and to provide relevant information to managers seeking to limit injury and mortality of oaks during restoration burns, we examined Oregon white oak response to prescribed burning, with specific focus on the differential and interactive impacts of above- and belowground fire on oak vigor. As mortality of oaks is generally low in prescribed burns (Sugihara and Reed 1987), we used crown bud kill, as evidenced by crown dieback, as a metric of oak injury. We asked if either the belowground effect of duff consumption, the above-ground fire effects (such as crown scorch), or a combination of effects influenced crown dieback. Additionally, as mortality models are commonly used by managers for planning prescribed burns and predicting the impacts of wildfires, we chose to evaluate the applicability of the First Order Fire Effects Model (FOFEM 6.4; Keane and Lutes 2017) in Oregon white oak woodlands. The mortality algorithms employed by the program were largely developed for conifer species, and its utility in Western oak ecosystems has not been thoroughly examined. Using our dataset for validation, we examined the model's ability to accurately predict mortality of oaks in our studied stands. This work has direct implications for fire management in the region, and perhaps more widely in oak woodlands where prescribed fire is employed for ecosystem restoration.

\section{Methods \\ Study area}

Study sites were located on Joint Base Lewis-McChord (JBLM), a 34802 ha military installation located in Thurston and Pierce counties, Washington, USA. The military base contains some of the largest and most intact prairie and oak woodland habitats in the western United States (Regan and Agee 2004), and maintains an active ecological prescribed fire program, treating approximately 750 ha annually (J. Richardson, personal communication) The dominant soil in the oak woodland sites is Spanaway gravelly sandy loam, a typical glacial outwash soil of the region (Zulauf 1979). Topography is flat to undulating, with an average elevation of $90 \mathrm{~m}$ above sea level (Thysell and Carey 2001). Climate in this region is mediterranean, with warm, dry summers (summer high temperatures average $25{ }^{\circ} \mathrm{C}$ ), and cool, wet winters. Annual precipitation averages $997 \mathrm{~mm}$, most of which falls between the months of October and May (Pringle 1990). During two of the five years preceding prescribed burns (2011 and 2013), precipitation in the area was recorded at below-normal levels, although neither of these were drought years (Western Regional Climate Center 2019).

\section{Pre-burn field data collection}

Four burn units were selected for measurement in two non-adjacent areas on the military installation. Two units were located in Holden Woods, close to the center of the installation (47.0591, -122.5099). The Holden Woods units, HLD01 and HLD02, were 8.9 ha and 6.9 ha in area, respectively, with a mixed herbaceous understory dominated by long-stolon sedge (Carex inops L.H. Bailey) and exotic grasses and forbs; approximately one third of each site was covered with a mix of snowberry (Symphoricarpos albus [L.] S.F. Blake) and low Oregongrape (Mahonia nervosa [Pursh] Nutt.). The most recent records of burning at this site date to a likely pile burn approximately 15 years prior to the study. Two additional burn units, adjacent but with distinct vegetation, were selected in the Upper Weir Prairies, near the town of Rainier, Washington (46.9165, -122.7094; UWTT and UWTB). The 2.8 ha UWTT unit was last burned in 2014, and had an herbaceous understory comprised largely of non-native perennial grasses (Agrostis capillaris L., Arrhenatherum elatius [L.] P. Beauv. ex J. Presl \& C. Presl, and Dactylis glomerata L.), with few shrubs. UWTB, which was 2 ha in area, had not burned in several decades, and had a shrub-dominated understory. A short, westfacing slope connected the two units. Dominant shrubs in both sites were Scotch broom (Cytisus scoparius [L.] Link), snowberry, and Himalayan blackberry (Rubus 
armeniacus Focke). Similar fuels reduction and nonnative species control treatments had been conducted recently in all burn units prior to our study. These treatments largely took the form of brush-cutting of mature Scotch broom throughout each unit, and served to reduce, but not eliminate, this invasive shrub from these sites ( $T$. Zuchowski, Fish and Wildlife Program, Joint Base LewisMcChord, Washington, USA, personal communication). All units had an Oregon white oak overstory and woodland structure, with the exception of UWTT (where most conifers had been previously removed), and had scattered conifers present. Douglas-fir was a minor component in both UWTB and the Holden Woods units, with the latter also containing large ponderosa pine (Pinus ponderosa Douglas ex C. Lawson).

Prior to each burn, we randomly selected approximately 50 oaks per burn unit $(n=201)$ that were at least $5 \mathrm{~cm}$ in diameter at $137 \mathrm{~cm}$ from ground level (DBH). Mean DBH in both Upper Weir units was $23 \mathrm{~cm}$, while mean DBH in the Holden Woods units was $18.7 \mathrm{~cm}$. We recorded each tree's location, $\mathrm{DBH}$, height, crown base height, and extent of any prior scarring. To facilitate postburn proportional duff consumption measurement, we inserted eight metal welding rods around the base of each tree $10 \mathrm{~cm}$ from the bole at cardinal and ordinal points. These rods were driven into mineral soil, and then cut to be flush with the upper surface of the duff.

Fuel moisture collections were made approximately one hour prior to ignition in each unit. Samples consisted of 1 - and 10-hour time lag woody fuels (dead wood less than $0.64 \mathrm{~cm}$ and $2.54 \mathrm{~cm}$ in diameter, respectively), live shrub foliage, live grasses, oak litter, and duff (combining Oe and Oa horizons from the bases of nearby unsampled oaks). Samples were sealed in polyethylene bags and transported to the laboratory for analyses. Each fuel sample was weighed wet and then oven-dried for 72 hours at $60{ }^{\circ} \mathrm{C}$, when no further weight loss occurred. Final dry weights were used to calculate mean gravimetric moisture content for each fuel type (Additional file 1).

\section{Day-of-burn fire conditions}

Burns took place during the summer dry season: both Upper Weir units and HLD01 were burned in August 2016, while HLD02 was burned in September 2017 (Additional file 2). Ambient air temperatures during burns were moderate, ranging from 18 to $28{ }^{\circ} \mathrm{C}$, while relative humidity (Rh) ranged from a high of $56 \%$ to a low of $32 \%$. Winds were generally light, averaging less than $5 \mathrm{~km} \mathrm{hr}^{-1}$, with maximum gusts briefly reaching $13.7 \mathrm{~km} \mathrm{hr}^{-1}$ during burns in the Upper Weir units. Flame lengths (based on ocular estimates of trained personnel) were generally low in all units, ranging from $0.3 \mathrm{~m}$ in backing fires, to a maximum of $3 \mathrm{~m}$ in head fires. Rates of spread (measured by taking the average time required for flame fronts to cross
Table 1 Field measurements used in analyses of prescribed fire effects on Q. garryana at Joint Base Lewis-McChord, Washington, USA, 2016 to 2018

\begin{tabular}{ll}
\hline Pre burn & Post burn \\
\hline $\begin{array}{l}\text { Tree characteristic predictors } \\
\text { Height }\end{array}$ & $\begin{array}{l}\text { Above-ground predictors } \\
\text { Diameter at breast } \\
\text { height (DBH) }\end{array}$ \\
$\begin{array}{l}\text { Crown base height } \\
\text { Prior scarring }\end{array}$ & Bole char at base (BCC) \\
& Percent crown volume scorched (PCVS) \\
& Percent crown volume consumed (PCVC) \\
& Percent crown volume flushing (PCVF) \\
& Below-ground predictors \\
& Proportional duff consumption \\
& Response metric \\
& Crown dieback (\%) \\
\hline
\end{tabular}

known distances) ranged from $0.01 \mathrm{~m} \mathrm{sec}^{-1}$ in backing fires to $0.13 \mathrm{~m} \mathrm{sec}^{-1}$ in head fires. All units were ignited using strip head-firing techniques (Martin and Dell 1978).

\section{Post-burn field data collection}

Initial fire effects on selected oaks in each unit were measured approximately two weeks after burns (Table 1). For each tree, we recorded the following above-ground metrics: maximum height of charring on the bole $(\mathrm{cm})$, percent circumference charred at the base (BCC) and at 137 $\mathrm{cm}$ (DBHCC), percent of crown volume scorched (PCVS), and percent of crown volume consumed (PCVC), following methods employed by Kobziar et al. (2006). Foliage was considered scorched if leaves were brown and wilted within two weeks of each burn (measurements of crown scorch were taken before seasonal leaf fall), and consumed if leaves were blackened or consumed in the fire. To assess effects of below-ground (smoldering) fire on measured trees, we measured depth of the pre-burn duff and depth of duff consumed at each welding rod location where consumption had occurred. We then used these measurements to calculate mean proportional duff consumption for each tree.

We examined quantity of late-season foliage production in oak crowns three months post burn (late October to early November 2016), measured as proportion of crown volume flushing (PCVF). These data were not collected in the HLD02 unit due to the late-season timing of the burn.

To assess Oregon white oak response to measured fire effects, we measured crown dieback as the proportion of the crown volume not producing leaves (assumed bud kill) nine months post burn (May 2017 for Upper Weir units and HLD01, July 2018 for HLD02); trees with no visible spring bud break were considered topkilled. All 
measured trees were re-evaluated in September of 2018 to assess their status (live, topkilled, dead) 25 months (for Upper Weir units and HLD01) and 13 months (for HLD02) post burn.

\section{Data analysis}

All analyses were conducted using $\mathrm{R}$ version 3.3.2 ( $\mathrm{R}$ Core Team 2016), and used pre- and post-burn data pooled from all measured trees, regardless of unit location. To test for spatial autocorrelation in response data that could be related to tree location, trees were grouped by location on the landscape, and Mantel tests were conducted on each of these groups using the vegan package (Mantel 1967; Oksanen et al. 2018). For each location, a distance matrix of response variables (fire effects) was compared to a distance matrix created from spatial coordinates for each tree location. Spatial coordinates were standardized by subtracting the minimum value from both latitude and longitude values before analysis, and response variables not already in proportional form were relativized by their maximum values in order to give each equal weight in the analysis. Euclidean distance calculations were used to create both dissimilarity matrices. Mantel tests yielded low correlations and non-significant results for both Holden Woods $(P=0.995)$ and the Upper Weir sites $(P=0.861)$. This allowed the remainder of the analyses to continue without the need to add additional terms to models in order to account for the effect of tree location within a unit.

Both above- and below-ground fire effects were evaluated for their contribution to crown injury. As collinearity existed between predictor variables related to tree size (DBH, height, and crown base height), a Principal Components Analysis (PCA) of these metrics was conducted using the prcomp function in the stats package in R. A vector of scores from the first axis of the PCA (comprising $70 \%$ of the variation in the data) was created for inclusion in modeling efforts. Linear modeling was used to evaluate the impacts of above- and below-ground fire effects on crown dieback observed in Oregon white oak crowns. All measured fire effects variables (bole char height, BCC, DBHCC, PCVS, proportional duff consumption), the variable created to represent tree size, and late-season flushing were modeled against crown dieback using stepwise regression (using the stepAIC function in the MASS package) in order to determine which effects were significantly correlated with post-fire crown dieback. A threshold significance value of 0.05 was used, and terms in the model were evaluated using Akaike information criterion (AIC), root mean square error (RMSE), and $R^{2}$ values to determine their effect in improving model accuracy. Differences in diameter between topkilled versus non-topkilled trees and the effects of prior scarring were evaluated using two-sample $t$-tests.

\section{Comparison with fire effects model}

In order to evaluate the effectiveness of current fire effects models at predicting mortality in Oregon white oak, we entered metrics collected or derived from our stand data (DBH, height, crown ratio, and scorch height) into the First Order Fire Effects Model (FOFEM) software. We then generated predicted mortality levels for each of our studied units, and compared these modeled predictions with observed oak responses, measured nine months post burn.

\section{Results}

The majority of recorded fire effects were variable across the four oak woodland prescribed burn units, even between adjacent Upper Weir sites (Table 2). Scorching of oak crowns was common in all three burn units, with more than $92 \%$ of trees experiencing some level of scorch; of these, mean quantity of scorch was $63 \%$ of crown volume. Ten percent of trees experienced some consumption of crown foliage, with only two of those having more than $10 \%$ of their crown consumed. Due to the rarity of this phenomenon, crown consumption was discarded from further analyses. Seventy-seven percent of trees had their boles charred in the burns; mean char height across all three units was $53.3 \mathrm{~cm}$. The UWTT unit had lower values for char height along the bole and at the base of trees, as well as quantity and proportion of duff consumption. Duff consumption averaged $21 \%$ across sites.

Late-season oak bud burst was minimal, with a mean of $10.1 \%$ crown volume producing fall foliage across sites, and only $23 \%$ of trees exhibiting this response. Quantity of scorching was related to late-season bud burst, with flushing oaks having experienced higher volumes of scorch $(P=0.011)$, but the effect size was small (model coefficient $=0.16$ ). Fall leaf flush did not occur

Table 2 Fire effects on measured Q. garryana in four burn units at Joint Base Lewis-McChord, Washington, USA, 2016 to 2018. Means are given, with standard deviations in parentheses. Missing data denoted by dashes. UWTT = Upper Weir Trenches unit T, UWTB = Upper Weir Trenches unit B, HLD01 = Holden Woods unit 1, HLD02 = Holden Woods unit 2, BCC = Bold char at base, $\mathrm{DBHCC}=$ bole char at breast height

\begin{tabular}{llllc}
\hline & UWTT & UWTB & HLD01 & HLD02 \\
\hline Bole char height (cm) & $28.8(37.6)$ & $91.6(108.8)$ & $54.7(48.8)$ & $38.1(74.4)$ \\
BCC (\%) & $19.7(26.2)$ & $50.3(31.8)$ & $70.02(33.88)$ & $25.8(36.5)$ \\
DBHCC (\%) & $2.0(8.33)$ & $15.8(25.6)$ & $5.7(17.6)$ & $5.6(19)$ \\
Crown scorch (\%) & $66.1(36.4)$ & $67.3(40.3)$ & $69.0(32.3)$ & $49.2(41.6)$ \\
Duff consumed (cm) & $0.3(0.6)$ & $1.6(1.5)$ & $3.3(2.8)$ & $0.6(1.2)$ \\
Duff consumed (\%) & $9.1(16.6)$ & $28.5(22.8)$ & $37.4(31.5)$ & $9.4(17.2)$ \\
Crown dieback (\%) & $26.0(31.7)$ & $33.6(30.7)$ & $29.8(31.4)$ & $21.9(25.9)$ \\
Fall sprouting (\%) & $10.0(23.7)$ & $11.3(22.8)$ & $9.2(21.7)$ & -- \\
\hline
\end{tabular}


in oaks that had less than $60 \%$ of their crowns scorched in burns.

Nine months following the four prescribed burns at JBLM, only 14 of tagged Oregon white oaks (7\%) were topkilled, and mean crown dieback values were less than 30\% of crown volume (Table 2). Smaller-diameter oaks were topkilled more readily than larger trees: topkilled trees had a mean DBH of $11.3 \mathrm{~cm}$, mean DBH of trees with live above-ground vegetation was $21.6 \mathrm{~cm}$ (Fig. $1, P=0.0001$ ). Of all measured fire effects, crown scorching was the strongest single predictor of crown dieback $\left(P<0.0001, \mathrm{R}^{2}\right.$ $=0.38$ ). Oak crown dieback was minimal below $80 \%$ volume scorched, ranging from 0 to $40 \%$ with a mean value of 9.8\% (Fig. 2). While topkill only occurred when entire oak crowns were scorched, high levels of scorching had widely variable effects on oak dieback (ranging from 0 to $100 \%$ ). Tree size mitigated the effect of total crown scorch, although this phenomenon did not explain a large portion of the variation in response (Fig. 3). Stepwise multiple linear regression comparing crown dieback with all measured fire effects resulted in the strongest model including the following predictors: scorch volume, charring at $\mathrm{DBH}$, tree size, and the interaction of tree size and scorch volume (Table 3; $P<0.0001$ ). Higher levels of crown scorching and bole charring at $\mathrm{DBH}$ were correlated with increased
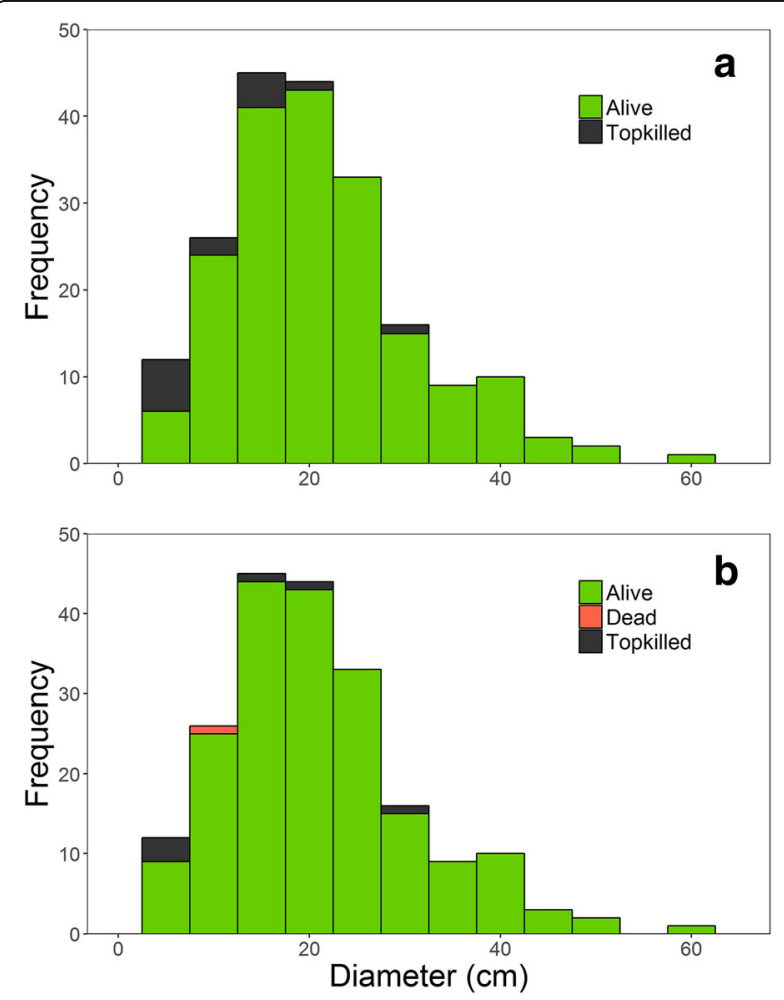

Fig. 1 Diameter distributions of living, dead, and topkilled oaks (a) nine months and (b) 15 and 25 months (May 2017, May 2018, and September 2018, respectively) following prescribed burns at Joint Base Lewis-McChord, Washington, USA dieback (model coefficients 0.36 and 0.24, respectively), while the interaction of tree size and scorch mitigated this relationship, with a negative influence on magnitude of dieback (model coefficient $=-0.13$ ). No collinearity existed between any of the modeled above-ground fire effects. Below-ground fire effects (proportional duff consumption) were not correlated with crown dieback $(P=0.1)$. As expected, greater duff depths were correlated with increased duff consumption $\left(P<0.0001, \mathrm{R}^{2}=0.59\right)$. Trees with scars on the tree bole had greater mean volumes of subsequent dieback (19.3\% for unscarred trees versus $31.7 \%$ for scarred trees, $P=0.006)$.

While the principal stems of 14 trees appeared dead in the spring following burns, subsequent surveys demonstrated that none of these trees were completely killed. Twenty-five months following the 2016 burns, 57\% percent of trees formerly deemed dead $(n=8)$ had begun to reestablish crown foliage via epicormic sprouting, and the remainder were basally sprouting from the root crown (Fig. 4). One tree that had live foliage nine months following prescribed burning died prior to remeasurement. No changes were recorded 15 months following the burn conducted in the HLD02 unit.

Our results differed substantially from stand mortality predictions produced by the FOFEM software (Table 4), even when allowing for topkill as a substitute for actual mortality. Using our stand metrics and observed fire effects, model outputs predicted high levels of mortality for all experimental units, with a mean of $64 \%$ predicted oak mortality for all stands, in contrast to the $3 \%$ topkill we observed 25 months following burns. Mean diameter of killed trees was predicted to be $19.2 \mathrm{~cm}$, while measured DBH of trees topkilled 25 months following prescribed burns had a mean of only $12.7 \mathrm{~cm}$, and only two oaks above $18.3 \mathrm{~cm}$ DBH were topkilled 25 months following burns (Fig. 2).

\section{Discussion}

Various mechanisms control woody plant responses to fire, with the maintenance of latent bud reserves and non-structural carbohydrate storage acting as effective methods of survival in fire-prone ecosystems (Clarke et al. 2013; Pausas and Keeley 2014). Our results demonstrate Oregon white oaks' high fire resilience, utilizing strategies of both fire-resisters (protective bark, heat-tolerant buds) and endurers (epicormic and basal sprouting) (Rowe 1983). The characteristic low severity of prescribed fires creates difficulty in modelling mortality for fire-tolerant species under this management regime, as Oregon white oaks are rarely killed in these treatments (Sugihara and Reed 1987).

Depending on management objectives, topkill and excessive crown dieback of mature oaks may be considered undesirable if the goal is to preserve an intact oak 


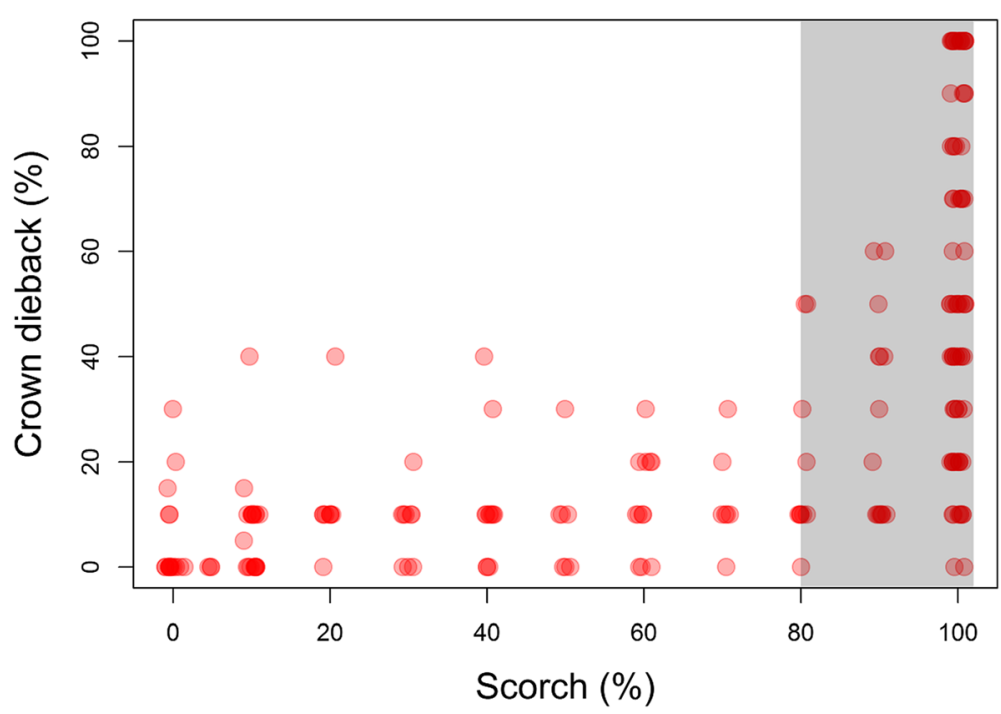

Fig. 2 Q. garryana crown dieback nine months following burns (May 2017 and 2018) as related to quantity of crown volume scorched in prescribed burns at Joint Base Lewis-McChord, Washington, USA. While response was highly variable, substantial crown injury was only observed above a threshold of $80 \%$ scorch (shaded area). Topkill of trees was not observed when complete (100\%) crown scorch did not occur

canopy. However, in many sites, fire exclusion has caused former open woodlands to increase in density, with resultant impacts on understory flora (Hosten et al. 2006; Livingston et al. 2016; Hanberry et al. 2017). In these situations, fire-induced topkill may serve to thin dense stands as well as to provide snags and downed wood, critical habitat elements for many native bird and wildlife species (Vesely and Tucker 2004; Hanberry et al. 2017). Regardless of managers' goals, the difficulty in predicting oak response following prescribed burns makes the crafting of burn prescriptions challenging using current decision support tools.
Not all fire effects contributed equally to dieback in oak crowns. Charring at DBH was a contributor to our final model, but as neither of the other bark char variables was significant, char height may simply be an indicator of substantial heat reaching the crown, and not a sign of underlying cambial damage (Hood et al. 2018). Trees with greater quantities of crown scorch were more likely to experience dieback the following spring, while tree size was a mitigating factor in the model. Larger oaks appeared to be better able to withstand a high level of scorching, likely due to the differential between the minimum temperatures necessary to kill leaves versus

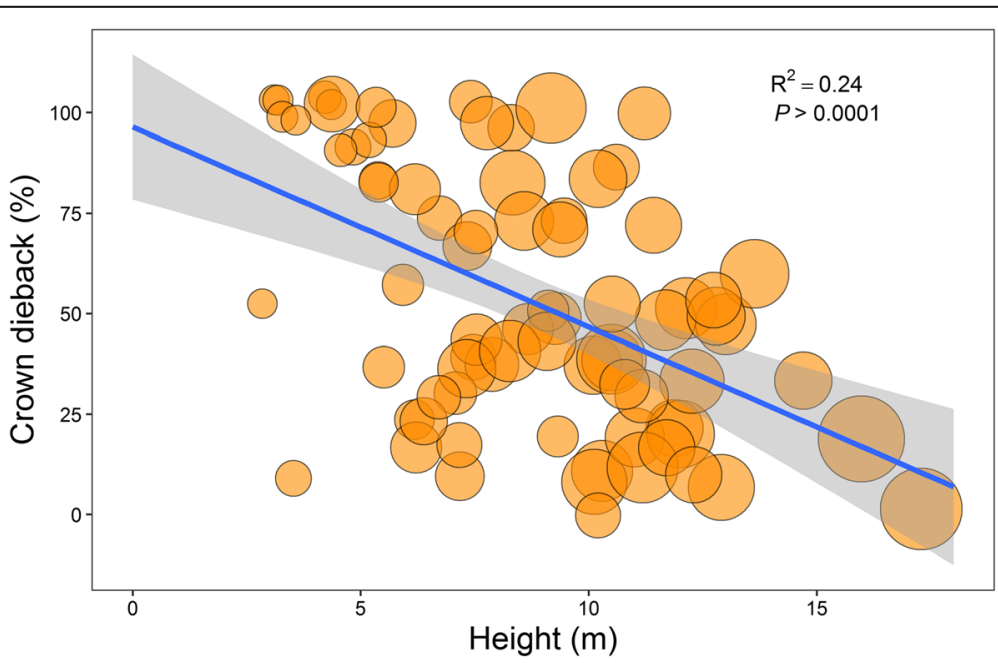

Fig. 3 Initial crown dieback of Q. garryana that experienced 100\% crown scorch in 2016 and 2017 prescribed burns at Joint Base Lewis-McChord, Washington, USA. Points are sized relative to tree diameter (DBH). Shaded area around linear regression line (blue) of crown dieback by tree height represents $95 \%$ confidence interval 
Table 3 Summary of multiple linear regression model fits of Q. garryana crown dieback nine months after burns, May 2016 and 2018, at Joint Base Lewis-McChord, Washington, USA. PCVS = percent crown volume scorched, DBHCC = bole char at breast height, $\mathrm{BCC}=$ bole char at base, $\mathrm{PCVSP}=$ percent crown volume sprouting

\begin{tabular}{|c|c|c|c|}
\hline \multirow[b]{2}{*}{ Model predictors } & \multicolumn{3}{|c|}{ Evaluation criteria } \\
\hline & RMSE & $R^{2}$ & $\triangle \mathrm{AlC}$ \\
\hline PCVS+DBHCC+tree size+PCVS*tree size (final model) & 19.7 & 0.57 & \\
\hline PCVS+DBHCC+tree size & 20.7 & 0.52 & 18 \\
\hline PCVS+DBHCC+PCVSP+tree size & 20.6 & 0.53 & 17 \\
\hline PCVS+DBHCC+Duff consumed (\%)+PCVSP+tree size & 20.5 & 0.53 & 18 \\
\hline PCVS+DBHCC+BCC+Duff consumed (\%)+PCVSP+tree size & 20.5 & 0.54 & 18 \\
\hline PCVS+Bole char height+DBHCC+BCC+Duff consumed (\%)+PCVSP+tree size & 20.5 & 0.54 & 20 \\
\hline
\end{tabular}

those temperatures that must be attained so that buds are damaged (Peter et al. 2011). Taller trees are protected from heating in aerial buds via attainment of escape height (Higgins et al. 2000; Bond 2008; Burrows et al. 2008), while the buds of smaller oaks are likely to be subjected to the greater heating that is linked to substantial bud damage (Peter et al. 2009, 2011). Additionally, increased diameter generally indicates greater bark thickness, which can offer protection from lethal heating to the underlying cambium (van Mantgem and Schwartz 2003; Clarke et al. 2013). It is also possible that, due to their increased carbohydrate reserves, mature oak trees have greater capacity to replace damaged tissues (Malanson and Trabaud 1988; Niemiec et al. 1995), although the relationship between ontogeny and resprouting ability varies among species (Bond and van Wilgen 1996; Vesk 2006). Similar correlations between tree size and crown injury have been documented in other prescribed fire studies (Ryan and Reinhardt 1988; Kobziar et al. 2006).

Scorching, our strongest predictor of crown injury, has been found to increase the probability of mortality in studies of conifer species (Ryan and Reinhardt 1988; Kobziar et al. 2006; Hood et al. 2010; Hood et al. 2018), but has not been well studied in oaks. Oregon white oak tolerance to crown scorching is commonly assumed to be high, but few studies have established this with certainty. Several authors have examined prescribed fire effects on Oregon white oak regeneration (Tveten and Fonda 1999; Regan and Agee 2004), and one of these measured crown scorch in trees (Regan and Agee 2004), but did not attempt to relate this effect to oak injury. Peter et al. (2009) found buds of Oregon white oaks to be highly resistant to heating, suffering very low bud mortality at even the highest treatment level (133 seconds of heating at $60{ }^{\circ} \mathrm{C}$, a threshold temperature commonly associated with plant tissue mortality). Thus, visible scorching of leaves in the crown may not indicate subsequent bud death with any certainty (as in Peter et al. 2011). If this is the case, it might explain the highly variable dieback response at higher levels of crown scorching that we observed (Fig. 2). If scorching in oak crowns does not have a direct relationship with bud mortality, it may be of limited value as a field assessment of post-fire injury in highly fire-resistant species such as Oregon white oak. Additionally, the wide variation in crown dieback may indicate that managers' efforts to protect oaks from crown scorching may not be warranted, especially for mature trees.

While we were unable to precisely predict post-fire oak crown injury based on effects of understory burns, there were some clear thresholds of tree response. Postfire crown sprouting did not occur below scorch volumes of $60 \%$, and more than $80 \%$ scorch was necessary for substantial (50\% or greater) crown dieback to occur. These results imply the existence of a high tolerance of Oregon white oaks to fire-induced injury, only beyond which will a response be observable in impacted trees. It appears that substantial injury must occur before imbalances are created in the hormones that regulate plant growth such that a sprouting response is provoked in adventitious buds (Anderson et al. 2001; Pyke et al. 2010). Correspondingly, bud death is also unlikely unless a tree is subjected to heat sufficient to scorch the entire crown.

The connection between basal duff consumption and oak vigor is less clear. One potential consequence of duff consumption for oak vigor is injury to fine roots due to heating as duff smolders following the passage of a flame front (Swezy and Agee 1991; Varner et al. 2009). Despite a number of trees experiencing considerable proportional duff consumption, we found no apparent negative impacts on oak vigor within two years of prescribed burns. Similarly, while Kobziar and others (Kobziar et al. 2006) found that basal charring was a significant predictor of California black oak (Q. kelloggii Newberry) mortality following prescribed burns, they concluded that duff consumption did not predict oak mortality eight months after burning. It is possible, however, that negative effects of duff consumption may be revealed over a longer time period than that covered by either our study or Kobziar et al. (2006) (Ryan and Reinhardt 1988; Agee 2003). Injury to fine roots, and the resulting reduction in water absorption and holding capacity, may only be detrimental if trees are 

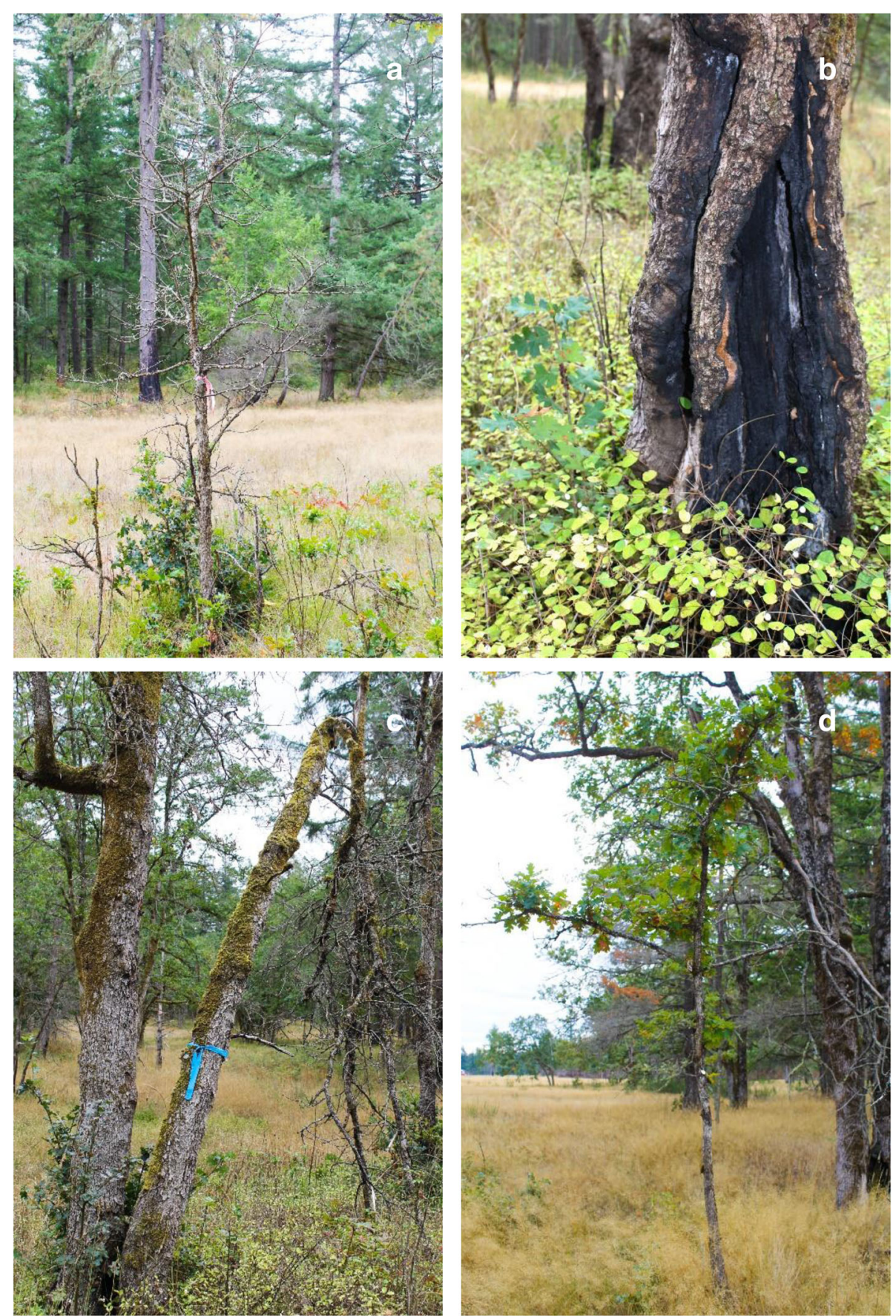

Fig. 4 Differing oak response to high levels of crown scorch: all depicted trees appeared topkilled nine months following prescribed burns at Joint Base Lewis-McChord, Washington, USA. Twenty-five months following burns (May 2018 for 2016 burn units), more than 50\% had reestablished live foliage in their crowns. Those that did not appeared to be more susceptible to topkill due to (a) small stature, (b) heavy scarring, or (c) previous injury. The remainder (d) had replaced substantial crown volumes upon remeasurement. Photos by D. Nemens

severely drought-stressed prior to burning, which was likely not the case in this study, or following burning, which has yet to be observed.

Another possible reason for this null result is that few fine roots were located in or close to the duff layer around the bases of studied trees. While Oregon white oak is generally considered to be a deep-rooted species with a long tap root, Devine and Harrington (2005) found that, in the coarse-textured glacial outwash soils of JBLM, the majority of fine lateral roots were located within the top $40 \mathrm{~cm}$ of the mineral soil profile. We did not examine fine oak roots embedded in duff prior to 
Table 4 Comparison of measured fire effects at Joint Base LewisMcChord, Washington, USA (2016 to 2018), with First Order Fire Effects Model predictions. For the purposes of comparison, topkill is equated with mortality as predicted in the model. $\mathrm{n} / \mathrm{a}=$ no tree mortality was observed in the unit. DBH = diameter at breast height, FOFEM = First Order Fire Effects Model, UWTT = Upper Weir Trenches unit T, UWTB = Upper Weir Trenches unit B, HLD01 $=$ Holden Woods unit 1, HLD02 $=$ Holden Woods unit 2

\begin{tabular}{llrrrrr}
\hline & \multicolumn{2}{l}{ Mean DBH of killed trees $(\mathrm{cm})$} & & \multicolumn{2}{c}{ Tree mortality (\%) } \\
\cline { 2 - 3 } & Observed & FOFEM modeled & & Observed & FOFEM modeled \\
\hline UWTT & $\mathrm{n} / \mathrm{a}$ & 8.5 & & 0 & 58 \\
UWTB & $\mathrm{n} / \mathrm{a}$ & 7.7 & 0 & 66 \\
HLD01 & 13.6 & 6.8 & 10 & 67 \\
HLD02 & 10.8 & 7.2 & 4 & 66 \\
\hline
\end{tabular}

burns; the quantity of fine roots underlying duff in the surficial mineral soil, and the amount of heating that occurred at these depths during burns, is not known. To our knowledge, no research in Oregon white oak has measured root ingrowth into deep organic duff, as has been recorded in other long-unburned ecosystems (Swezy and Agee 1991; O’Brien et al. 2010). While our results indicated that, as in other systems, duff consumption in Oregon white oak woodlands was greater with deeper duff depths (Frandsen 1987; Hungerford et al. 1995; Kreye et al. 2017), greater duff accumulation in long-unburned stands does not necessarily confer greater risk to mature oaks in restoration burns.

Post-fire bud burst is a commonly observed but little understood phenomenon in Oregon white oaks. Similar to our observations, other researchers have documented a late-season flush of crown foliage following burns in Oregon white oaks (Peter et al. 2011). When injured, oaks are capable of sprouting both from the crown and base of the tree (Fry 2002; Gucker 2007). While post-fire sprouting is a common mechanism for regeneration following disturbance, this additional expenditure of carbohydrates at the end of the growing season may diminish reserves available for crown repair in the spring following low-intensity surface fire, and thus reduce spring leaf production. Conversely, there might be a net gain for the tree if these new leaves are able to generate excess carbohydrates, which may be readily available the following spring. We did not observe an effect, either positive or negative, of late-season foliage production on oak vigor within two seasons of the prescribed burns in this study. To our knowledge, this phenomenon has been little studied, and the impact of fall bud burst on oak vigor and spring leafing response is unknown.

Similarly, we were unable to find studies documenting or attempting to explain the delayed crown recovery that we observed two years following burns in a few previously leafless trees. It is possible that the epicormic growth that occurred took some time to develop due to resprouting tissues having to penetrate thick branch bark (D. Peter, USDA Forest Service Pacific Northwest Research Station, Olympia, Washington, USA, personal communication). Epicormic resprouting from the crown is common in angiosperms, but bud primordia may be located more deeply underneath bark in some species compared to others (Clarke et al. 2013). It is likely that meristematic tissues are deeply buried in Oregon white oak bark, in order to confer greater protection from heating in the canopy (van Mantgem and Schwartz 2003; Bond 2008; Burrows et al. 2008; Clarke et al. 2013), but the tradeoff for this protection may be a delay or even failure of epicormic resprouting following crown injury (Johnson et al. 2009).

The results of mortality modeling using the FOFEM program deviated substantially from our observed results, with predicted mortality an order of magnitude greater than observed topkill (Table 4). As the algorithm used in this model is not based on data from Oregon white oak mortality studies, but instead a general, non-speciesspecific equation derived from studies of conifer fire response, this is not an unexpected finding (Ryan and Amman 1994; Keane and Lutes 2017). The magnitude of the prediction error, however, is considerable, and demonstrates the need for more accurate fire effects models for use in oak-dominated ecosystems. Of particular note are the variables upon which the FOFEM model relies in order to predict mortality-in the case of Q. garryana, bark thickness (which is in turn derived from DBH) and proportional crown scorch. Both of these metrics present issues for the modeling of mortality, and may constitute large sources of error, leading to the significant departure from our observations in the field. The fire effects model documentation indicates that the relationship between DBH and bark thickness is assumed to be linear: while a common simplification, this is rarely the case, and has not been established for Oregon white oak (Jackson et al. 1999). Other studies have found that these models can underpredict bark thickness, potentially leading to overestimation of mortality in fires (Zeibig-Kichas et al. 2016; Kane et al. 2017). Moreover, FOFEM employs a common bark thickness coefficient for all oak species, an assumption that likely adds considerable error to the model. Issues with the poor predictive ability of crown scorch for oak topkill, outlined above, likely contributed to the overprediction of mortality by using an algorithm that relies on a strong correlation between these two variables. The inaccuracy of the Ryan-Amman model when applied to oaks has been documented in other studies, and, while our data indicate that predicting mortality, or even topkill, is difficult for this species, incorporating a species-specific model into the FOFEM program would nevertheless 
greatly improve its predictive ability (Hood et al. 2010; Kane et al. 2017).

Their high level of resistance and resilience to fire, coupled with great variability in post-fire response, make Oregon white oak mortality and topkill prediction challenging. This is particularly the case in short-duration studies such as this one, as the manifestation of post-fire tree injury is often delayed (Ryan and Reinhardt 1988; Agee 2003). However, Oregon white oak mortality is uncommon following understory burns (Thysell and Carey 2001; Regan and Agee 2004), indicating that, while substantial injury to mature Oregon white oaks is possible, the risk of mortality is quite low. Our results hint at the existence of other factors (such as tree age or pre-burn vigor), unmeasured in this study, that may influence outcomes for oaks in restoration fires. Additional studies, including long-term monitoring, may clarify the relationship between fire effects and oak injury in prescribed burns.

\section{Conclusions}

While many studies have been conducted in longunburned conifer-dominated systems (Hood et al. 2018), to our knowledge this is the first study to compare both above- and below-ground fire effects of restoration burns in Oregon white oak woodlands. While this research is intended to be followed by long-term monitoring of studied stands, the preliminary results presented here may help to guide management decisions in the near future. The remarkable resilience of fire-excluded Oregon white oak demonstrated in this study indicates that extraordinary precaution on the part of managers reintroducing fire into these systems may not be warranted; however, continued monitoring to evaluate longer-term impacts, as well as impacts from more burns under a greater range of conditions, will be necessary to establish this with more certainty.

\section{Additional files}

Additional file 1: Average day-of-burn fuel moisture values in four $Q$. garryana woodland burn units at Joint Base Lewis-McChord, Washington, USA, August 2016 and 2017. UWTT = Upper Weir Trenches unit T, UWTB $=$ Upper Weir Trenches unit B, HLD01 = Holden Woods unit 1, HLD02 = Holden Woods unit 2. (PDF $147 \mathrm{~kb}$ )

Additional file 2: Day-of-burn conditions for four Q. garryana woodland burn units at Joint Base Lewis-McChord, Washington, USA, August 2016 and September 2017. UWTT $=$ Upper Weir Trenches unit T, UWTB $=$ Upper Weir Trenches unit B, HLD01 $=$ Holden Woods unit 1, HLD02 $=$ Holden Woods unit 2, Rh $=$ relative humidity. Asterisk $\left(^{*}\right)=$ data not available. (PDF $155 \mathrm{~kb}$ )

\section{Acknowledgements}

The staff at JBLM and the Center for Natural Lands Management provided access to burn units and valuable discussions on research needs. We particularly appreciate the assistance of S. Krock, J. Richardson, K. Hill, N. Miller, T. Zuchowski, M. McKinley, B. Wilken, C. Harrington, and especially D. Buckingham and his team of interns. Additional field assistance was provided by G. Hamby, T. Shearman, T. Tohn, and J. Cronan. D.S. Rinnan and H.
Podschwit provided extensive statistical consultation. E. Alvarado and J. Hille Ris Lambers, as well as two anonymous reviewers provided helpful comments and suggestions on earlier versions of this manuscript.

\section{Authors' contributions}

DGN designed the study, and collected and analyzed the data. JMV provided substantial guidance on design and methodology, and provided field assistants. DGN, JMV, and PD all contributed to the writing of the manuscript. All authors read and approved the final manuscript.

\section{Funding}

Funding for this research was provided by the National Fire Plan and the Joint Fire Science Program.

\section{Availability of data and materials}

The datasets used or analyzed during the current study are available from the corresponding author on request.

Ethics approval and consent to participate

Not applicable.

Consent for publication

Not applicable.

\section{Competing interests}

The authors declare that they have no competing interests.

Received: 28 November 2018 Accepted: 6 June 2019

Published online: 07 August 2019

References

Agee, J.K. 1993. Fire ecology of Pacific Northwest forests. Washington, D.C.: Island Press.

Agee, J.K. 1996. Fire in restoration of Oregon white oak woodlands. In The use of fire in forest restoration. USDA Forest Service General Technical Report INT-GTR-341, ed. C.C. Hardy and S.F. Arno, 72-73. Ogden: USDA Forest Service, Intermountain Research Station.

Agee, J.K. 2003. Monitoring postfire tree mortality in mixed-conifer forests of Crater Lake, Oregon, USA. Natural Areas Journal 23: 114-120.

Altman, B. 2011. Historical and current distribution and populations of bird species in prairie-oak habitats in the Pacific Northwest. Northwest Science 85: 194-222 https://doi.org/10.3955/046.085.0210.

Anderson, J.V., W.S. Chao, and D.P. Horvath. 2001. A current review on the regulation of dormancy in vegetative buds. Weed Science 49: 581-589 https://doi.org/10.1614/0043-1745(2001)049[0581:RCROTR]2.0.CO;2.

Babb, G.D. 1992. Sprouting response of Quercus arizonica and Quercus emoryi following fire. Thesis. Tucson: University of Arizona.

Bond, W.J. 2008. What limits trees in $C_{4}$ grasslands and savannas? Annual Review of Ecology, Evolution, and Systematics 39: 641-659 https://doi.org/10.1146/ annurev.ecolsys.39.110707.173411.

Bond, W.J., and J.E. Keeley. 2005. Fire as a global 'herbivore': the ecology and evolution of flammable ecosystems. Trends in Ecology \& Evolution 20: $387-$ 394 https://doi.org/10.1016/j.tree.2005.04.025.

Bond, W.J., and B.W. van Wilgen. 1996. Fire and plants. Population and Community Biology Series, volume 14. Dordrecht: Springer https://doi.org/10.1007/978-94009-1499-5.

Burrows, G.E., S.K. Hornby, D.A. Waters, S.M. Bellairs, L.D. Prior, and D.M.J.S. Bowman. 2008. Leaf axil anatomy and bud reserves in 21 Myrtaceae species from northern Australia. International Journal of Plant Sciences 169: 1174-1186 https:// doi.org/10.1086/591985.

Chappell, C.B., and R.C. Crawford. 1997. Native vegetation of the South Puget Sound prairie landscape. In Ecology and conservation of the South Puget Sound prairie landscape. ed P.V. Dunn and K. Ewing, 107-122. Seattle: The Nature Conservancy.

Clarke, P.J., M.J. Lawes, J.J. Midgley, B.B. Lamont, F. Ojeda, G.E. Burrows, N.J. Enright, and K.J.E. Knox. 2013. Resprouting as a key functional trait: how buds, protection and resources drive persistence after fire. New Phytologist 197: 19-35 https://doi.org/10.1111/nph.12001.

Cole, D. 1977. Ecosystem dynamics in the coniferous forest of the Willamette Valley, Oregon, USA. Journal of Biogeography 4: 181-192 https://doi.org/10. 2307/3038162. 
Crawford, R.C., and H. Hall. 1997. Changes in the south Puget prairie landscape ecology and conservation of the South Puget Sound prairie landscape. In Ecology and conservation of the South Puget Sound prairie landscape, ed. P.V. Dunn and K. Ewing, 11-15. Seattle: The Nature Conservancy.

Dennehy, C., E.R. Alverson, H.E. Anderson, D.R. Clements, R. Gilbert, and T.N. Kaye. 2011. Management strategies for invasive plants in Pacific Northwest prairies, savannas, and oak woodlands. Northwest Science 85: 329-351 https://doi.org/ 10.3955/046.085.0219.

Devine, W.D., and C.A. Harrington. 2005. Root system morphology of Oregon white oak on a glacial outwash soil. Northwest Science 79: 179-188.

Dunwiddie, P.W., and J.D. Bakker. 2011. The future of restoration and management of prairie-oak ecosystems in the Pacific Northwest. Northwest Science 85: 83-92 https://doi.org/10.3955/046.085.0201.

Engber, E.A., and J.M. Varner. 2012. Reversing conifer encroachment with prescribed fire: shifting mortality models toward restoration targets. Restoration Ecology 20: 665-668 https://doi.org/10.1111/j.1526-100X.2012.00900.x.

Frandsen, W.H. 1987. The influence of moisture and mineral soil on the combustion limits of smoldering forest duff. Canadian Journal of Forest Research 17: 1540-1544 https://doi.org/10.1139/x87-236.

Fry, D.L. 2002. Effects of a prescribed fire on oak woodland stand structure. In Proceedings of the fifth symposium on oak woodlands: oaks in California's changing landscape. USDA Forest Service General Technical Report PSW-GTR-184, Technical coordination by R.B. Standiford, D. McCreary, and K.L. Purcell, 235-242. Albany: USDA Forest Service, Pacific Southwest Research Station.

Gucker, C.L. 2007. Quercus garryana. In Fire Effects Information System. USDA Forest Service, Rocky Mountain Research Station https://www.fs.fed.us/ database/feis/plants/tree/quegar/all.html Accessed 8 Nov 2019.

Hamman, S.T., P.W. Dunwiddie, J.L. Nuckols, and M. McKinley. 2011. Fire as a restoration tool in Pacific Northwest prairies and oak woodlands: challenges, successes, and future directions. Northwest Science 85: 317-328 https://doi. org/10.3955/046.085.0218.

Hanberry, B.B., J.M. Kabrick, P.W. Dunwiddie, T. Hartel, T.B. Jain, and B.O. Knapp. 2017. Restoration of temperate savannas and woodlands. In Routledge handbook of ecological and environmental restoration, ed. S.K. Allison and S.D. Murphy, 142-157. Abingdon-on-Thames: Taylor and Francis, Routledge https://doi.org/10.4324/9781315685977-11.

Higgins, S.I., W.J. Bond, and W.S.W. Trollope. 2000. Fire, resprouting and variability: a recipe for grass-tree coexistence in savanna. Journal of Ecology 88: 213-229 https://doi.org/10.1046/j.1365-2745.2000.00435.x

Hood, S.M., S.L. Smith, and D.R. Cluck. 2010. Predicting mortality for five California conifers following wildfire. Forest Ecology and Management 260: 750-762 https://doi.org/10.1016/j.foreco.2010.05.033.

Hood, S.M., J.M. Varner, P. van Mantgem, and C.A. Cansler. 2018. Fire and tree death: understanding and improving modeling of fire-induced tree mortality. Environmental Research Letters 13: 113004 https://doi.org/10. 1088/1748-9326/aae934.

Hosten, P.E., O.E. Hickman, F.K. Lake, F.A. Lang, and D. Vesely. 2006. Oak woodlands and savannas. In Restoring the Pacific Northwest: the art and science of ecological restoration in Cascadia, ed. D. Apostol and M. Sinclair, 63-96. Washington, D.C.: Island Press.

Hungerford, R.D., W.H. Frandsen, and K.C. Ryan. 1995. Ignition and burning characteristics of organic soils. Tall Timbers Fire Ecology Conference 19:78-91.

Jackson, J.F., D.C. Adams, and U.B. Jackson. 1999. Allometry of constitutive defense: a model and a comparative test with tree bark and fire regime. The American Naturalist 153: 614-632 https://doi.org/10.1086/303201.

Johnson, P.S., S.R. Shifley, and R. Rogers. 2009. The ecology and silviculture of oaks. Second edition. Wallingford: CAB International https://doi.org/10.1079/ 9781845934743.0000

Kane, J.M., P.J. van Mantgem, L.B. Lalemand, and M. Keifer. 2017. Higher sensitivity and lower specificity in post-fire mortality model validation of 11 western US tree species. International Journal of Wildland Fire 26: 444-454 https://doi.org/ 10.1071/WF16081

Keane, R., and D. Lutes. 2017. First Order Fire Effects Model: FOFEM Version 6.4. USDA Forest Service, Rocky Mountain Research Station. https://www.firelab. org/project/fofem Accessed 8 Nov 2018.

Kobziar, L., J. Moghaddas, and S.L. Stephens. 2006. Tree mortality patterns following prescribed fires in a mixed conifer forest. Canadian Journal of Forest Research 36: 3222-3238 https://doi.org/10.1139/x06-183.

Kreye, J.K., J.M. Varner, C.J. Dugaw, E.A. Engber, and L.N. Quinn-Davidson. 2017. Patterns of duff ignition and smoldering beneath old Pinus palustris: influence of tree proximity, moisture content, and ignition vectors. Forest Science 63:165-172. https://doi.org/10.5849/forsci.2016-058

Larsen, E.M., and J.T. Morgan. 1998. Management recommendations for Washington's priority habitats. Oregon white oak woodlands. Olympia: Washington Department of Fish and Wildlife.

Livingston, A.C., J.M. Varner, E.S. Jules, J.M. Kane, and L.A. Arguello. 2016. Prescribed fire and conifer removal promote positive understorey vegetation responses in oak woodlands. Journal of Applied Ecology 53: 1604-1612 https://doi.org/10.1111/1365-2664.12703.

Malanson, G.P., and L. Trabaud. 1988. Vigour of post-fire resprouting by Quercus coccifera L. The Journal of Ecology 76 (2): 351-365 https://doi.org/10.2307/2260598.

Mantel, N. 1967. The detection of disease clustering and a generalized regression approach. Cancer Research 27: 209-220.

Martin, R.E., and J.D. Dell. 1978. Planning for prescribed burning in the Inland Northwest. USDA Forest Service General Technical Report PNW-66. Portland: USDA Forest Service, Pacific Northwest Research Station.

Miyanishi, K., and E.A. Johnson. 2002. Process and patterns of duff consumption in the mixedwood boreal forest. Canadian Journal of Forest Research 32: 1285-1295 https://doi.org/10.1139/×02-051.

Niemiec, S.S., G.R. Ahrens, S. Willits, and D.E. Hibbs. 1995. Hardwoods of the Pacific Northwest. Research Contribution 8. Corvallis: Oregon State University, College of Forestry, Forest Research Laboratory.

Nowacki, G.J., and M.D. Abrams. 2008. The demise of fire and "mesophication" of forests in the eastern United States. BioScience 58: 123-138 https://doi.org/10. 1641/B580207.

O'Brien, J.J., J.K. Hiers, R.J. Mitchell, J.M. Varner, and K. Mordecai. 2010. Acute physiological stress and mortality following fire in a long-unburned longleaf pine ecosystem. Fire Ecology 6 (2): 1-12 https://doi.org/10.4996/ fireecology.0602001.

Oksanen, J.F., G. Blanchet, M. Friendly, R. Kindt, P. Legendre, D. McGlinn, P.R. Minchin, R.B. O'Hara, G.L. Simpson, P. Solymos, M.H.H. Stevens, E. Szoecs, and H. Wagner. 2018. vegan: community ecology package. R package version 2.46. https://CRAN.R-project.org Accessed 20 Sept 2018.

Pausas, J.G., and J.E. Keeley. 2014. Evolutionary ecology of resprouting and seeding in fire-prone ecosystems. New Phytologist 204: 55-65 https://doi.org/ 10.1111/nph.12921.

Peter, D.H., J.K. Agee, and D.G. Sprugel. 2009. Bud damage from controlled heat treatments in Quercus garryana. Trees 23: 381-390 https://doi.org/10.1007/ s00468-008-0287-7.

Peter, D.H., J.K. Agee, and D.G. Sprugel. 2011. Effects of prescribed burning on leaves and flowering of Quercus garryana. Trees 25: 679-688 https://doi.org/ 10.1007/s00468-011-0545-y.

Pringle, R.F. 1990. Soil survey of Thurston County, Washington. Spokane: USDA Soil Conservation Service, Washington State Department of Natural Resources and Washington State University.

Pyke, D.A., M.L. Brooks, and C.M. D'Antonio. 2010. Fire as a restoration tool: a decision framework for predicting the control or enhancement of plants using fire. Restoration Ecology 18: 274-284 https://doi.org/10.1111/j.1526-100X.2010.00658.x.

R Core Team. 2016. R: a language and environment for statistical computing. Vienna: R Foundation for Statistical Computing.

Regan, A.C., and J.K. Agee. 2004. Oak community and seedling response to fire at Fort Lewis, Washington. Northwest Science 78: 1-11.

Rowe, J.S. 1983. Concepts of fire effects on plant individuals and species. In The role of fire in northern circumpolar ecosystems, ed. R.W. Wein and D.A. MacLean, 135-154. New York: Wiley.

Ryan, K.C., and G.D. Amman. 1994. Interactions between fire-injured trees and insects in the Greater Yellowstone Area. In Plants and their environments: proceedings of the first biennial scientific conference on the Greater Yellowstone Ecosystem, ed. D.G. Despain, 259-271, Yellowstone National Park: United States Department of the Interior, National Park Service.

Ryan, K.C., and E.D. Reinhardt. 1988. Predicting postfire mortality of seven Western conifers. Canadian Journal of Forest Research 18: 1291-1297 https:// doi.org/10.1139/x88-199.

Schriver, M., R.L. Sherriff, J.M. Varner, L. Quinn-Davidson, and Y. Valachovic. 2018 Age and stand structure of oak woodlands along a gradient of conifer encroachment in northwestern California. Ecosphere 9 (10): e02446 https:// doi.org/10.1002/ecs2.2446.

Sprenger, C.B., and P.W. Dunwiddie. 2011. Fire history of a Douglas-fir-Oregon white oak woodland, Waldron Island, Washington. Northwest Science 85: 108-119 https://doi.org/10.3955/046.085.0203. 
Staver, A.C., S. Archibald, and S. Levin. 2011a. Tree cover in sub-Saharan Africa: rainfall and fire constrain forest and savanna as alternative stable states. Ecology 92: 1063-1072 https://doi.org/10.1890/10-1684.1.

Staver, A.C., S. Archibald, and S.A. Levin. 2011. The global extent and determinants of savanna and forest as alternative biome states. Science 334: 230-232 https://doi.org/10.1126/science.1210465.

Stephens, S.L., and M.A. Finney. 2002. Prescribed fire mortality of Sierra Nevada mixed conifer tree species: effects of crown damage and forest floor combustion. Forest Ecology and Management 162: 261-271 https://doi.org/10. 1016/S0378-1127(01)00521-7.

Sugihara, N.G., and L.J. Reed. 1987. Prescribed fire for restoration and maintenance of Bald Hills oak woodlands. In Proceedings of the symposium on multiple-use management of California's hardwood resources. USDA Forest Service General Technical Report PSW-GTR-100. Technical coordination by: T.R. Plumb and N.H. Pillsbury, 446-451. Berkeley: USDA Forest Service, Pacific Southwest Forest and Range Experiment Station.

Sugihara, N.G., J.W. van Wagtendonk, and J. Fites-Kaufman. 2006. Fire as an ecological process. In Fire in California's ecosystems, ed. N.G. Sugihara, J.W. van Wagtendonk, K.E. Shaffer, J. Fites-Kaufman, and A.E. Thode, 58-74. Berkeley: University of California Press https://doi.org/10.1525/california/ 9780520246058.003.0004.

Swezy, D.M., and J.K. Agee. 1991. Prescribed-fire effects on fine-root and tree mortality in old-growth ponderosa pine. Canadian Journal of Forest Research 21: 626-634 https://doi.org/10.1139/x91-086.

Taylor, A.H., and C.N. Skinner. 2003. Spatial patterns and controls on historical fire regimes and forest structure in the Klamath Mountains. Ecological Applications 13: 704-719 https://doi.org/10.1890/1051-0761(2003)013[0704: SPACOH]2.0.CO;2.

Thysell, D.R., and A.B. Carey. 2001. Quercus garryana communities in the Puget Trough, Washington. Northwest Science 75: 219-235.

Tveten, R.K., and R.W. Fonda. 1999. Fire effects on prairies and oak woodlands on Fort Lewis, Washington. Northwest Science 73: 145-158.

van Mantgem, P.J., and M. Schwartz. 2003. Bark heat resistance of small trees in Californian mixed conifer forests: testing some model assumptions. Forest Ecology and Management 178: 341-352 https://doi.org/10.1016/S03781127(02)00554-6.

Varner, J.M., D.R. Gordon, F.E. Putz, and J.K. Hiers. 2005. Restoring fire to longunburned Pinus palustris ecosystems: novel fire effects and consequences for long-unburned ecosystems. Restoration Ecology 13: 536-544 https://doi.org/ 10.1111/j.1526-100X.2005.00067.x.

Varner, J.M., F.E. Putz, J.J. O'Brien, J.K. Hiers, R.J. Mitchell, and D.R. Gordon. 2009. Post-fire tree stress and growth following smoldering duff fires. Forest Ecology and Management 258: 2467-2474 https://doi.org/10.1016/j.foreco. 2009.08.028.

Vesely, D., and G. Tucker. 2004. A landowner's guide for restoring and managing Oregon white oak habitats. Salem: US Bureau of Land Management https:// doi.org/10.5962/bhl.title.144988.

Vesk, P.A. 2006. Plant size and resprouting ability: trading tolerance and avoidance of damage? Journal of Ecology 94: 1027-1034 https://doi.org/10. 1111/j.1365-2745.2006.01154.x

Western Regional Climate Center. 2019. WRCC monthly climate summaries. https://wrcc.dri.edu/Climate/summaries.php. Accessed 29 Apr 2019.

Zeibig-Kichas, N.E., C.W. Ardis, J.P. Berrill, and J.P. King. 2016. Bark thickness equations for mixed-conifer forest type in Klamath and Sierra Nevada mountains of California. International Journal of Forestry Research 2016: 1864039 https://doi.org/10.1155/2016/1864039.

Zulauf, A.S. 1979. Soil survey of Pierce County area. Washington. Olympia: USDA Soil Conservation Service.

\section{Publisher's Note}

Springer Nature remains neutral with regard to jurisdictional claims in published maps and institutional affiliations.

\section{Submit your manuscript to a SpringerOpen ${ }^{\odot}$ journal and benefit from:}

- Convenient online submission

- Rigorous peer review

- Open access: articles freely available online

- High visibility within the field

- Retaining the copyright to your article

Submit your next manuscript at $\boldsymbol{\nabla}$ springeropen.com 